\title{
A magyar tókepiaci szabályozás, különös tekintettel az új befektetési formák megjelenésére
}

\section{Capital Market Regulation in Hungary, with Special Focus on the Emergence of New Forms of Investment}

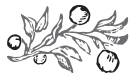

Összefoglalás

A tanulmány röviden áttekinti a magyar tốkepiaci szabályozás néhány fontosabb szegmensét. Bemutatja a tôzsdékre vonatkozó szabályokat, valamint a befolyásszerzés menetét. Emellett az új típusú befektetési formák közül is ismerteti az érdekesebb típusokat, mint például az ismertnek tekinthetố hedge fundokat, valamint a magyar jogban viszonylag új elemnek számító szabályozott ingatlanbefektetési társaságokat. A tanulmány fố megállapítása, hogy a magyar tôkepiaci jog fejlôdése illeszkedik a nemzetközi tendenciákba.
\end{abstract}

Journal of Economic Literature (JEL) kódok: K20, K29, K22

Kulcsszavak: tôkepiac, Magyarország, alternatív befektetési alapok, szabályozott ingatlanbefektetési társaságok

Summary

The paper gives a brief summary of some of the significant segments in capital market regulation, such as the stock exchanges and the rules of acquisition. A description is

Dr. Habil. Kecskés András PhD, tanszékvezetô egyetemi docens, Pécsi Tudományegyetem Állam- és Jogtudományi Kar (kecskes.andras@ajk.pte.hu) 
given of the more important new forms of investment, including hedge funds and regulated property companies, the former known, the latter relatively new in Hungarian law. The main conclusion of the paper is that the development of Hungarian capital market law fits into the international trends.

Journal of Economic Literature (JEL) codes: K20, K29, K22

Keywords: capital market, Hungary, alternative investment funds, regulated property companies

\section{BEVEZETÉS}

A tanulmány célja rövid áttekintést adni a magyar tôkepiaci jog szabályozási rendszeréről, és ismertetni néhány alapvetést a tôzzsdérôl és a tőkepiacokról. Ezzel összefüggésben nem feledkezhetünk meg a vállalatfelvásárlásokra vonatkozó jogi szabályozási környezetrôl sem, amely viszonylag újnak tekinthetố a magyar jogban. Nem volna teljes a körkép a - nemzetközi üzleti élet gyakorlata alapján megjelent - új befektetési formák és azok szabályozásának bemutatása nélkül, ezért a tanulmány második része az alternatív befektetési alapok magyarországi szabályozását tekinti át, kitérve a hedge fundokra mint az egyik leginkább elterjedt alternatív befektetési formára. Ezenkívül bemutatjuk a szabályozott ingatlanbefektetési társaságot, amely amerikai mintára jelent meg a magyar jogban. A magyar tôkepiaci jog fejlódését erôteljesen determinálják a nemzetközi gazdasági folyamatok, valamint az európai uniós szabályozási környezet (Lentner, 2017; Lentner-Zéman, 2017), így a tanulmány idônként a nemzetközi példákra is kitekintést nyújt.

\section{TőKEPIACI JOGI SZABÁLYOZÁS}

A magyar tôkepiaci jogra vonatkozó szabályok jelentős része a 2001:CXX. törvény (tôkepiaci törvény) rendelkezései között találhatók meg. Ugyanakkor más jogszabályok is tartalmaznak a tôkepiaci múködéssel összefüggésbe hozható szabályokat, így például a Polgári törvénykönyvrôl szóló 2013:V. törvény jogi személyekrôl szóló 3. könyvében megtalálhatjuk a nyilvánosan múködó részvénytársaságra vonatkozó szabályokat, a kötelmi jogról szóló 6. könyvben pedig az értékpapírokra vonatkozó háttérszabályokat.

\section{A tôzsde és a tôzsdei tevékenység}

A tőzsde egy koncentráltan és szervezetten múködó piac, ahol az értékpapírokkal való kereskedelem szabályozott formában történik (Kecskés, 2016:463). A tôkepiaci törvény II. fejezet definíciója alapján a tôzsde „a hatékony tôkeáramlás, tôkeértékelés, az árfolyam és egyéb kockázat megosztása érdekében a tôzsdei termékek keresletét és 
Kecskés András: A magyar tôkepiaci szabályozás, különös tekintettel az új befektetési formák...

kínálatát koncentráló, azok kereskedését lebonyolító, a nyilvános árfolyam-alakulást elôsegítô vállalkozás”. A tôkepiaci törvény meghatározása értelmében tôzsdei tevékenység „a tôzsdei termék szervezett, szabványosított kereskedésének üzletszerú lebonyolítása”. A magyar szabályozás alapján tôzsdei tevékenységet kizárólag tôzsde végezhet. A tőzsdére a Polgári törvénykönyv (Ptk.) jogi személyekre vonatkozó rendelkezéseit, fióktelep formájában múködó tốzsdére pedig a külföldi vállalkozások magyarországi fióktelepéról szóló 2003:LIV. törvény (Fkt.) rendelkezéseit kell alkalmazni a tôkepiaci törvényben foglalt eltérésekkel. Tózsde alapítása csak a Pénzügyi Szervezetek Állami Felügyelete, illetve 2013-tól a felügyeleti tevékenységet ellátó MNB (továbbiakban: Felügyelet) engedélyével, továbbá dematerializált részvényekkel rendelkezó részvénytársasági formában, illetve külföldi tôzsde fióktelepe formájában történhet. Tózsde árualapú ügyletek, deviza-, valamint határidôs kamatlábügyletek kereskedése esetén legalább százötven millió, egyéb tốzsdei termék kereskedése esetén legalább ötszázmillió forint pénzben befizetett alaptókével (jegyzett tókével) alapítható. A törvény által meghatározott keretek között a tózsde szabályzatban határozza meg a tevékenységére, illetve a tôzsdei kereskedôkre és kibocsátókra vonatkozó szabályokat (Kecskés, 2016b).

\section{A tốzsdei kereskedés szabályai}

Tózsdei kereskedố az a személy lehet, aki 1) legalább egy, az adott tơzsdén forgalmazott tôzsdei termék kereskedésének folytatásához szükséges felügyeleti, illetve más hatósági engedéllyel rendelkezik; 2) megfelel a tózsde szabályzataiban foglalt feltételeknek; 3) a tôzsdével megköti a szerződést, melyben vállalja a tôzsde szabályzataiban előírt feltételek teljesítését, betartását; 4) a tôzsdei ügyletek elszámolására szerzôdést kötött a központi szerzôdó féllel, illetve központi értéktárral vagy olyan klíringtaggal, melyen keresztül az elszámolás teljesíthetô. A kereskedési jog tartalmát és gyakorlásának feltételeit a tôzsde szabályzatában határozzák meg. A tôzsde jogosult a tôzsdei kereskedóktôl azok tôzsdén folytatott tevékenységével kapcsolatos, illetve azt befolyásoló információk kérésére, gyújtésére. A tôzsdei kereskedési jog megszúnésével (a tôzsdei kereskedô megszúnése, halála, a tôzsdei kereskedési szerzôdés felmondása stb.) kapcsolatos szabályokat a tôkepiaci törvény 316. §-a tartalmazza (Kecskés, 2016b).

\section{A tôzsdei ügyletek típusai}

A tôzsdei ügylet az a szerződés, amelyet a tôzsdei kereskedô a tôzsdén - a tôzsdei szabályzat által lehetôvé tett körben és módon - tôzsdei termékre vonatkozóan köt. A tôzsdei ügylet azonnali, határidôs és opciós ügylet és ezek kombinációja lehet.

- Azonnali ügylet: ha a tôzsdei ügyletben az ügylet tárgyának tényleges átadására anélkül vállalnak kötelezettséget, hogy a teljesítés módját és idejét meghatározták volna, a kötelezettséget a tôzsdei szabályzatban meghatározott módon és idóben kell teljesíteni. Ilyen pl. a részvények, kötvények azonnali vétele vagy eladása.

- Határidôs ügylet: a szerzôdó felek megállapodhatnak abban, hogy a tôzsdei ügyletben vállalt kötelezettségeiket a tôzsdei szabályzat által meghatározott, késôb- 
bi időpontban teljesítik. A származékos ügyletek tipikus példái a határidős ügyleteknek.

- Opciós ügylet: alapvetốn két különbözô típusú opciós ügyletet határolunk el. Ha a kötelezett tôzsdei termékre másnak vételi jogot enged, a jogosult a vételi jog tárgyát egyoldalú nyilatkozattal megvásárolhatja (vételi opció). Annak a személynek, aki a jogosulttal szemben a tôzsdei termékre vételi kötelezettséget vállal, a jogosult a tốzsdei terméket egyoldalú nyilatkozattal eladhatja (eladási opció). Azonban az Egyesült Államokkal ellentétben, az opciós piacok Magyarországon nem képesek hasonló likviditási, illetve tôkésítési szint elérésére, fenntartására (Kecskés, 2016b).

A transzparens tôkepiaci múködés alapfeltétele a bennfentes kereskedelem és a piaci manipuláció széles körú visszaszorítása.

\section{A bennfentes kereskedelem és a piaci manipuláció szabályozása a tôkepiaci törvényben és az uniós jogban}

A tôkepiaci törvény bennfentes kereskedelemről és a piaci manipulációról szóló rendelkezései 2016. július 1-jétől közvetlenül a piaci visszaélésekról szóló 596/2014/EU rendelet szabályaira utal. A rendelet 14. cikke tilalmazza a bennfentes kereskedelmet és annak kísérletét, másik személy részére bennfentes kereskedelem folytatására vonatkozó tanácsadást, rábírását, és szintén tiltja a bennfentes információk jogosulatlan közzétételét. A rendelet 8 . cikke a bennfentes kereskedelem fogalmát a következôképp ragadja meg:

- Bennfentes kereskedelem az, amikor a bennfentes információkkal rendelkezó személy ezeket az információkat felhasználja oly módon, hogy közvetlenül vagy közvetve, saját vagy harmadik személy javára az információhoz kapcsolódó pénzügyi eszközöket szerez meg vagy idegenít el.

- Szintén bennfentes kereskedelemnek minôsül a bennfentes információ felhasználása az információhoz kapcsolódó pénzügyi eszközre szóló megbízás visszavonása vagy módosítása révén akkor, ha az adott személy a bennfentes információhoz a megbízást követôen jutott hozzá.

- A kibocsátási egységeknek vagy az azokon alapuló egyéb aukciós termékeknek az 1031/2010/EU rendelet szerint megtartott aukciója esetében a bennfentes információ felhasználásának minôsül az is, amikor valamely személy saját javára vagy harmadik személy javára megad, módosít vagy visszavon egy ajánlatot.

Az 596/2014/EU rendelet bennfenntes kereskedelemnek minősíti azt is, amikor egy személy másik személynek a bennfentes kereskedelemben való részvételt tanácsolja vagy másik személyt a bennfentes kereskedelemben való részvételre rábírja. Ennek egyik fontos feltétele, hogy a tanácsot adó vagy a részvételre rábíró személy bennfentes információval rendelkezzen, és 1) ezen információ alapján a másik személynek azt tanácsolja, hogy olyan pénzügyi eszközöket szerezzen meg vagy idegenítsen el, amelyekre az információ vonatkozik, vagy rábírja a másik személyt ezek megszerzésére vagy elidegenítésére; vagy 2) ezen információ alapján a másik személynek azt tanácsolja, hogy olyan pénzügyi eszközökre vonatkozó megbízást vonjon vissza vagy 
Kecskés András: A magyar tôkepiaci szabályozás, különös tekintettel az új befektetési formák...

módosítson, amelyekre az információ vonatkozik, vagy rábírja a másik személyt ezek visszavonására vagy módosítására. A tanács vagy rábírás felhasználása vagy további átadása bennfentes kereskedelemnek minôsül, ha a tanácsot vagy rábírást felhasználó vagy átadó személy tudja vagy tudnia kellene, hogy az bennfentes információn alapul.

A rendelet 15. cikke kimondja, hogy tilos a piaci manipuláció és annak kísérlete. A tôkepiaci törvény korábbi, piacbefolyásolásról szóló szabályaihoz képest sokkal részletesebben rendelkezik a rendelet 12. cikke, amelynek (1) bekezdése értelmében piaci manipulációnak minôsül:

- olyan ügylet kötése, vételi vagy eladási megbízás adása, vagy olyan egyéb magatartás, amely 1) hamis vagy félrevezetó jelzéseket ad, vagy valószínúsíthetôen adhat valamely pénzügyi eszköz, kapcsolódó azonnali árutőzsdei ügylet vagy kibocsátási egységeken alapuló aukciós termék kínálata, kereslete vagy ára tekintetében; vagy 2) a szokásostól eltérố vagy mesterséges szinten rögzíti, vagy valószínúsíthetôen rögzítheti egy vagy több pénzügyi eszköz, kapcsolódó azonnali árutôzsdei ügylet vagy kibocsátási egységeken alapuló aukciós termék árát. Ezek alól kivételt képez, ha az ügyleteket kötô, vételi vagy eladási megbízást adó vagy bármely más magatartást tanúsító személy bizonyítja, hogy az ilyen ügylet, megbízás vagy magatartás indokai jogszerúek, és megfelelnek valamely, a rendelet 13. cikkében megállapított, elfogadott piaci gyakorlatnak;

- olyan ügylet kötése, vételi vagy eladási megbízás adása, vagy olyan egyéb tevékenység vagy magatartás, amely egy vagy több pénzügyi eszköz, kapcsolódó azonnali árutôzsdei ügylet vagy kibocsátási egységeken alapuló aukciós termék árát érinti vagy érintheti, és amelynek során fiktív eszközhöz vagy a megtévesztés, félrevezetés egyéb formájához folyamodnak;

- olyan információk terjesztése az internetet is magában foglaló tömegtájékoztatásban vagy bármilyen más eszközzel, amelyek valamely pénzügyi eszköz, kapcsolódó azonnali árutőzsdei ügylet, kibocsátási egységeken alapuló aukciós termék kínálata, kereslete vagy ára tekintetében hamis vagy félrevezetô jelzéseket adnak vagy valószínúsíthetôen adhatnak, vagy a szokásostól eltérô vagy mesterséges szinten rögzítik egy vagy több pénzügyi eszköz, kapcsolódó azonnali árutőzsdei ügylet vagy kibocsátási egységeken alapuló aukciós termék árát, beleértve híresztelések terjesztését, ha a terjesztô személy tudta vagy tudnia kellett volna, hogy az információ hamis vagy félrevezetó;

- valamely referenciaértékre vonatkozóan hamis vagy félrevezetô információk továbbítása, hamis vagy félrevezetô adatok közlése, ha az információt továbbító vagy az adatokat közlő személy tudta, vagy tudnia kellett volna, hogy az információk vagy az adatok hamisak vagy félrevezetőek, továbbá valamely referenciaérték kiszámításának manipulálására irányuló bármely magatartás.

A rendelet a jogalkalmazás megkönnyítése érdekében, példálózó jelleggel, felsorol olyan magatartásokat, amelyek piaci manipulációnak minősülnek, így például személyek összejátszása, amelynek célja az erôfölény biztosítása pénzügyi eszköz, kapcsolódó azonnali árutôzsdei ügylet vagy kibocsátási egységeken alapuló aukciós termék kínálata, kereslete tekintetében, de idetartozhat a tömegtájékoztatásban való szereplés ki- 
Polgári Szemle $\cdot 15$. évfolyam 1-3. szám

használása, hogy a piaci árfolyamokat manipulálják. A rendelet I. számú melléklete tartalmazza a megtévesztés és félrevezetés egyéb formájának alkalmazására, valamint a hamis vagy félrevezetô jelzésekre és az árfolyamrögzítésre utaló jeleket.

\section{Befolyásszerzés nyilvánosan múködő részvénytársaságban}

Az egyes tôkepiaci szereplők térnyerése a tôkekoncentráció során nemcsak befektetôvédelmi, de nemzetgazdasági stratégiai kérdéseket is felvethet, ezért nagy hangsúlyt kell helyezni a szabad tôkeáramlás és a befektetôk hosszú távú érdekeinek összhangjára a szabályozás során.

\section{Az önkéntes vételi ajánlatra vonatkozó rendelkezések}

A tôkepiaci törvény alapján, vételi ajánlat útján történó befolyásszerzésre akkor is sor kerülhet, ha a vételi ajánlat tétele nem kötelezô. Más szavakkal élve, lehetôség van önkéntes vételi ajánlat realizálódására is. Önkéntes vételi ajánlat útján történő befolyásszerzésre a kötelezô vételi ajánlat útján történô befolyásszerzés szabályai irányadóak azzal az eltéréssel, hogy a céltársaság igazgatósága nem köteles a vételi ajánlatot véleményezni, illetve pénzügyi tanácsadót megbízni, továbbá a vételi ajánlatot nem kötelezó a részvénytársaság valamennyi szavazati jogot megtestesítő részvényére megtenni. Továbbá önkéntes vételi ajánlat esetén ellenajánlat nem tehetô. Az ajánlattevô, az ajánlattevó befolyásoló részesedése alatt álló vállalkozás, valamint a vele összehangoltan eljáró személyek, ${ }^{1}$ illetve bármelyikük megbízásából harmadik személy újabb önkéntes vételi ajánlatot az önkéntes vételi ajánlat lezárásától számított hat hónapon belül nem tehet. Ha az elfogadó nyilatkozatokban felajánlott részvények száma a vételi ajánlatban meghatározott mértéket meghaladja, a részvények átruházására kizárólag a részvények névértékének arányában kerülhet sor (Kecskés-Halász, 2013).

\section{Kötelezô nyilvános vételi ajánlat}

A tôkepiaci törvény alapján a céltársaságban² való huszonöt százalékot meghaladó mértékú befolyásszerzéshez (ha a befolyást szerzố részvényesen kívül senki sem rendelkezik a szavazati jogok tíz százalékát meghaladó befolyással), illetve a harminchárom százalékot meghaladó mértékú befolyásszerzéshez a Felügyelet által előzetesen jóváhagyott nyilvános vételi ajánlatot kell tenni.

Az értékpapírok forgalomba hozataláról, a befektetési szolgáltatásokról és az értékpapírtőzsdérôl szóló 1996:CXI. törvény 33\%-os határértéket állapított meg ebben a vonatkozásban, így ebben a tekintetben a tôkepiaci törvény lényeges változást nem hozott (Sándor, 2002:139). A befolyás mértékének megállapítása során a közvetlen és közvetett befolyást és az összehangoltan eljáró személyek, valamint a közeli hozzátartozó befolyásának mértékét egybe kell számítani. A befolyás mértékének megállapítása során a harmadik személy által a saját nevében, de a részvényes javára történô szavazati joggyakorlást a részvényes szavazati jogaként, a szerzôdést biztosító 
Kecskés András: A magyar tôkepiaci szabályozás, különös tekintettel az új befektetési formák...

mellékkötelezettségként biztosítékul adott részvény alapján, a részvényest megilletô szavazati jogot pedig a biztosíték jogosultjának szavazati jogaként kell figyelembe venni (Kecskés-Halász, 2013). Az ajánlattételi kötelezettséget nem kell alkalmazni a részvényesek rendes közgyúlésein történő szavazati jogot meg nem testesítô értékpapírok megszerzése esetében, így a 2004/25/EK irányelv preambulumának 11. pontja, illetve a 2. cikk (1) e. pontja érvényesül a magyar tôkepiaci szabályozásban is. A vételi ajánlatot a részvénytársaság valamennyi szavazati jogot megtestesítô részvényére és valamennyi szavazati joggal rendelkezó részvényese számára kell megtenni (Kecskés-Halász, 2013).

A tókepiaci törvény értelmében amennyiben a fentebb meghatározott határértéket meghaladó befolyás megszerzésére nem a befolyást szerzó közvetlenül erre irányuló magatartása következtében, vagy vételi jog, visszavásárlási jog érvényesítése, illetôleg határidős vételi megállapodás teljesítése alapján, illetve állami vagyonkezelố szervezet által lefolytatott, törvényben szabályozott eljárás keretében, vagy összehangoltan eljáró személyek együttmúködése eredményeképpen került sor, akkor a vételi ajánlatot legkésôbb a közzétételtôl számított tizenöt napon belül meg kell tenni. Ezen esetekben is az uniós irányelvhez igazodik a magyar szabályozás, az ilyen esetekben az ajánlatokat a lehetô legkorábban meg kell tenni (KecskésHalász, 2013).

Fontos eltérés a magyarországi és az európai szabályozás között, hogy míg az irányelv 5. cikk (1) bekezdése kimondja, hogy a kötelezó vételi ajánlatot a korábban szerzett, a társaság irányítását lehetôvé tevô értékpapírokra kell megtenni, addig a tőkepiaci törvény értelmében az ajánlatot elôzólegesen kell megtenni. Más szavakkal, az EU-s szabályozás alapján az ajánlattételi kötelezettség a befolyásszerzés eredményeképp jön létre, míg a magyarországi szabályozás alapján ez a kötelezettség a befolyásszerzés előfeltételeként jelentkezik (Gadó, 2000:16). A magyar szabályozás ebben a vonatkozásban hatékonyabb védelmet nyújt a kisebbségi részvényesek számára, ugyanakkor nem ró kedvezótlenebb feltételeket az ajánlattevôre, mint a közösségi szabályozás. Az elôzólegesen megteendô vételi ajánlat esetében is hasonló a helyzet, mivel az irányelv csupán azt határozza meg, hogy az ajánlatot a lehetố legkorábban kell megtenni, míg a tôkepiaci törvény 15 napos határidôt állapít meg (Kecskés-Halász, 2013).

Összehangoltan eljáró személyek befolyásszerzése esetén a vételi ajánlat megtételére valamennyi szerzôdó fél együttesen köteles, kivéve, ha a felek megállapodnak a vételi ajánlatot tevô személyérôl. A vételi ajánlat megtételére kötelezett személyében való megállapodás nem mentesíti a feleket a vételi ajánlat megtételével kapcsolatos feleloosség alól. A vételi ajánlat útján történố befolyásszerzés lebonyolítására befektetési szolgáltatót kell megbízni. Az ajánlattevố valamennyi felajánlott részvényt köteles megvásárolni, kivéve, ha az elfogadó nyilatkozatok alapján az ajánlattevố nem szerezne a céltársaságban ötven százalékot meghaladó befolyást, és a vételi ajánlat erre az esetre tartalmazta az elállás jogának fenntartását. A vételi ajánlat elfogadására vonatkozó jogosultság gyakorlása során tilos megsérteni a részvényesek között az egyenlő bánásmód követelményét (Kecskés-Halász, 2013). 
Polgári Szemle $\cdot$ 15. évfolyam 1-3. szám

Határidők a vételi ajánlat elfogadására

A törvény biztosítja a céltársaság részvényeseinek a kelló idôt egy megfelelóen átgondolt döntés meghozatalára. A tôkepiaci törvény kimondja, hogy a vételi ajánlat elfogadására nyitva álló határidô legalább harminc nap, legfeljebb hatvanöt nap lehet. A megszabott határidő az EU-s szabályozásban előírt határidő duplája, ugyanakkor a maximumként meghatározott 65 nap biztosítja, hogy az ajánlat elfogadásával vagy elutasításával kapcsolatos döntés észszerú idôn belül megszülessen. Az elfogadó nyilatkozat megtételére nyitva álló határidô kezdőnapja nem lehet korábbi idôpont, mint a közzététel megjelenését követô második nap, és nem lehet késóbbi idôpont, mint a közzétételt követô ötödik nap. A Felügyelet a kérelmezô ajánlattevô indokolt kérelmére, az elfogadó nyilatkozat megtételére a vételi ajánlatban meghatározott határidôt egyszer, legfeljebb tizenöt nappal meghosszabbíthatja. A kérelmezô legkésóbb az eredeti határidô lejártáig közzéteszi a határidô meghosszabbításának tényét (Kecskés-Halász, 2011).

Az elfogadó nyilatkozat megtételére nyitva álló határidő kezdő napját követően valamennyi, az ajánlat tárgyát képezô részvénnyel rendelkezô részvényes bejelentheti, hogy részvényét vagy annak az elfogadó nyilatkozatban meghatározott részét a vételi ajánlatban foglalt feltételek szerint át kívánja ruházni. Az elfogadó nyilatkozatot személyesen vagy meghatalmazott útján lehet megtenni. Az elfogadó nyilatkozat meghatalmazott, illetve közremúködô (pl. posta) útján történô megtételével kapcsolatos felelósség az elfogadó nyilatkozatra jogosultat terheli. Az elfogadó nyilatkozat nem vonható vissza. Az ajánlattevô, illetve az általa megbízott befektetési szolgáltató köteles az ajánlattétel elfogadására nyitva álló határidô utolsó napjától számított 2 naptári napon belül bejelenteni a Felügyelethez az ajánlattételi eljárás eredményét, illetve egyidejúleg köteles azt a vételi ajánlatok közzétételére vonatkozó szabályoknak megfelelôen közzétenni (Kecskés-Halász, 2013).

Az ajánlati ár meghatározása

Az ajánlati ár minimumát a tókepiaci törvény komplexebb módon határozza meg, mint a 2004/25/EK irányelv idevonatkozó rendelkezései. A törvény tartalmazza a piacra bevezetett és be nem vezetett részvények ellenértékének részletes meghatározását, mely megoldást az uniós irányelv nem alkalmazza. A piacra bevezetett, illetve a piacra be nem vezetett részvények ellenértékének meghatározása során a tôkepiaci törvényben az uniós jog „méltányos ár” elve érvényesül, ennek keretében számos alternatív ármeghatározási lehetôséget tartalmaz, melyek közül a legmagasabb tesz eleget az irányelv meghatározott „méltányos ár” követelményének. Az ellenérték meghatározásánál a vételi ajánlat Felügyelet részére történô benyújtását megelőzố száznyolcvan nap forgalommal súlyozott tôzsdei átlagárát, ${ }^{3}$ illetve az ajánlattevô, valamint a kapcsolt személyek által a vételi ajánlat benyújtását megelôzố száznyolcvan napon belül a céltársaság részvényeire ellenérték fejében kötött átruházási szerzôdés legmagasabb árát akkor is figyelembe kell venni, ha az elsố kereskedési nap és a vételi ajánlat 
Kecskés András: A magyar tôkepiaci szabályozás, különös tekintettel az új befektetési formák...

Felügyelet részére történô benyújtása között eltelt idô kevesebb, mint száznyolcvan nap, de a kilencven napot meghaladja.

Amennyiben rendelkezésre áll, a vételi ajánlat Felügyelet részére történố benyújtását megelôzoô háromszázhatvan nap forgalommal súlyozott tôzsdei átlagárát is figyelembe kell venni. ${ }^{4}$ A törvény értelmében az ajánlattevó az elfogadásra nyitva álló határidô záró napjáig a vételi ajánlatot az ellenérték tekintetében módosíthatja, feltéve, hogy a módosított ellenérték forintban meghatározott értéke meghaladja az ajánlatban meghatározott értéket, és a módosítást az ajánlattevô közzéteszi. Az ellenérték módosítása kiterjed a módosítás közzététele elôtt tett elfogadó nyilatkozatokra is (Kecskés-Halász, 2011).

A semlegességi (neutralitási) szabály

A semlegességi szabály (2004/25/EK irányelv 9. cikk (2) bekezdés) előírja, hogy attól az időponttól kezdődően, amikor a céltársaság tudomást szerez az ajánlattételrôl, a céltársaság ügyviteli vagy irányító szerve köteles megszerezni a részvényesek közgyúlésének kizárólag e célból adott elôzetes felhatalmazását bármely olyan intézkedés - más ajánlatok keresése kivételével - előtt, ami az ajánlattételi eljárás megzavarását eredményezheti (Kecskés-Halász, 2013).

A magyar tôkepiaci szabályozás a semlegességi szabályt a tôkepiaci törvény 73./A. § (1) bekezdésében is érvényesíti. Ennek értelmében ha a céltársaság alapszabálya ezt elôírja, a céltársaság igazgatósága, igazgatótanácsa, illetve felügyelőbizottsága a vételi ajánlat kézhezvételének idôpontjától vagy a vételi ajánlattétel szándékáról történô tudomásszerzés időpontjától a vételi ajánlat elfogadására nyitva álló idôszakon belül nem hozhat olyan döntést, amely alkalmas a befolyásszerzésre irányuló eljárás megzavarására (így nem határozhat az alaptôke felemelésérôl, a társaság saját részvényeinek megszerzésérôl stb.). Nem minôsül az alapszabályi tilalom megsértésének, ha a céltársaság igazgatósága a vételi ajánlat megtételét vagy az arra vonatkozó tudomásszerzést követốn a Ptk. jogi személyekre vonatkozó rendelkezései szerint összehívott közgyúlésen elfogadott határozata alapján, a határozatban nevesített esetekben és módon jár el. Ez ugyanakkor nem zárja ki, hogy a céltársaság döntéshozó szerve olyan tevékenységeket fejtsen ki, melyek egy ellenajánlat realizálódását eredményezhetik. A törvény értelmében az elfogadó nyilatkozat megtételére nyitva álló határidô zárónapját megelôzó tizenötödik napig bárki jogosult új vételi ajánlat (ellenajánlat) megtételére. Az ellenajánlatra a vételi ajánlatra vonatkozó rendelkezéseket kell alkalmazni. Az ellenajánlat akkor tehető közzé, és a Felügyelet akkor hagyja jóvá, ha az a részvényesek számára kedvezóbb, mint a vételi ajánlat vagy a korábbi ellenajánlat. Az ellenajánlat akkor minôsül kedvezóbbnek, ha az legalább öt százalékkal magasabb forintban kifejezett ellenértéket tartalmaz. Ha újabb ellenajánlatra kerül sor, ez az ellenajánlat akkor minősül kedvezőbbnek, ha legalább további öt százalékkal magasabb forintban meghatározott ellenértéket határoz meg, mint a korábbi ellenajánlat. A semlegességi szabály nem zárja ki azt, hogy a céltársaság igazgatósága a tôkepiaci törvény 75 . § szerinti ellenajánlat megtételének ösztönzése végett eljárjon, illetôleg, hogy a köz- 
gyúlés által az ajánlata kézhezvételének idôpontját megelőzően elfogadott határozat végrehajtása érdekében hozzon döntést, feltéve, hogy az a céltársaság szokásos üzleti tevékenységének körébe tartozik. A céltársaság igazgatósága ezen eljárása során a céltársaság hosszú távú üzleti, stratégiai jelentôségú céljainak figyelembevételével köteles eljárni (Kecskés-Halász, 2013).

\section{Az áttörés szabályai}

Az áttörés szabályai a tôkepiaci törvény 76/A. ${ }^{5}$ és 76/B. ${ }^{6}$ paragrafusaiban találhatók. A törvény értelmében a céltársaság alapszabálya előírhat bizonyos, az ajánlattevố fél helyzetét könnyítô feltételeket (Kecskés-Halász, 2013). A rendelkezés lényege abban áll, hogy amennyiben egy részvényes egy társaság meghatározott tulajdoni hányadát (magas részesedésrôl, 75\%-ról van szó) megszerzi, úgy automatikusan megszerzi annak irányítási jogait is, függetlenül a társaságon belül hatályos belsố megállapodásoktól (Kecskés, 2010). E célból az ajánlattevơnek joga van a részvényesek közgyúlését rövid úton összehívni. Ezúton az ajánlattevơ módosíthatja a céltársaság alapszabályát, és amennyiben úgy dönt, új menedzsmentet nevezhet ki, így az ajánlattevô formálhatja a céltársaság jövőbeni, illetve jelenlegi üzletpolitikáját. Az áttörés alkalmazásának mintegy ellentételezéseként a céltársaság részvényeseit eladási jog illeti meg a befolyásszerzóvel szemben, mellyel a 75\%-os vagy azt meghaladó befolyásszerzés közzétételétôl számított 90 napon belül élhetnek. A vételi árat a „méltányos ár” elve alapján kell megállapítani. A törvény kimondja, hogy az eladási jogát gyakorló részvényes által felajánlott részvény vételára megegyezó a vételi ajánlatban meghatározott vételárral, illetve ha a közgyúlést összehívó részvényes az eltelt idôszakban ennél magasabb áron vásárolt részvényeket, akkor a vételár e magasabb értékkel egyezik meg. A magyar szabályozás ezen túlmenôen további védekezési mechanizmusokat bocsát azon társaságok részére, melyek közgyúlése a szavazatelsôbbségi jog áttörésének lehetôségérôl határoz. Előírja továbbá, hogy ha a szavazatelsôbbségi részvényesnek az érintett részvény megszerzésekor nem volt, illetve nem lehetett tudomása a részvény által megtestesített szavazati jog gyakorlására vonatkozó korlátozás esetleges bekövetkezéséról, s e korlátozás következtében kára keletkezik, számára az ajánlattevootôl, illetve az áttörést megvalósító személytôl, illetve egyéb szervezettôl kártalanítás jár. A kártalanítás minimális mértékérôl a céltársaság alapszabályában kell rendelkezni, mely nem haladhatja meg a céltársaság törzsrészvénye értékének annyiszorosát, ahányszoros szavazati jogot a szavazatelsôbbségi részvény hordoz. Látható tehát, hogy a magyar törvényalkotó a társaságok (pontosabban azok közgyúlésének) kezében hagyja az ellentételezés mértéke meghatározásának jogát (Kecskés-Halász, 2013).

A vételi és eladási jog gyakorlása

Vételi jogának érvényesítésével az ajánlattevônek lehetôsége nyílik a befolyásszerzéssel nem érintett, tehát a tulajdonába nem került részvények megszerzésére, ezáltal a kisebbségi részvényesek jelentette kockázat elkerülésére. A vételi jog gyakorlása hatásos 
Kecskés András: A magyar tôkepiaci szabályozás, különös tekintettel az új befektetési formák...

eszköz a céltársaság részvényei 100\%-ának megszerzésére és a kisebbségi részvényesek „kivásárlására”. Ezzel szemben a kisebbségi részvényeseket eladási jog illeti meg a befolyásszerzôvel szemben (Kecskés-Halász, 2011).

A magyar törvényhozó három feltételt állapít meg a vételi jog gyakorlásának tekintetében: elôször is, az ajánlattevônek nyilatkoznia kell a Felügyelet felé arról, hogy vételi joggal kíván élni. Második feltételként az ajánlattevớ a sikeres vételi ajánlat, illetve az önkéntes vételi ajánlat lezárását követố három hónapon belül kilencven százalékot elérố vagy azt meghaladó mértékú befolyással rendelkezik a céltársaságban. Harmadik feltételként az ajánlattevőnek igazolnia kell, hogy megfelelő fedezettel rendelkezik a vételi jog tárgyát képezô részvények megszerzéséhez. Ebben a tekintetben az irányelv csak az ajánlattétel vonatkozásában ír elố igazolási kötelezettséget. Amennyiben a három feltétel teljesül, a tôkepiaci törvény alapján az ajánlattevố a vételi ajánlat, illetve az önkéntes vételi ajánlat lezárását követô három hónapon belül vételi jogot gyakorolhat a céltársaságnak a tulajdonába nem került részvényei tekintetében.

Ezt követôen az ajánlattevố bejelenti a Felügyeletnek, és egyidejúleg közzéteszi a vételi jog gyakorlására vonatkozó szándékát. A bejelentés és a közlemény tartalmazza a részvények átadás-átvételének helyét, idejét és módját, ellenértékét, megfizetésének idejét és módját. Az ajánlattevő az ellenértéket a vételi jog gyakorlása bejelentésével egyidejúleg az Európai Unió tagállamában székhellyel rendelkezó hitelintézetnél nyitott letéti számlán a céltársaság részvényesei javára elhelyezi.

A vételi jog gyakorlásának eredményeképpen megszerzendó részvények ellenértéke a vételi ajánlatban, illetve az önkéntes vételi ajánlatban meghatározott vételár és az egy részvényre jutó saját tôke ${ }^{7}$ értéke közül a magasabb összeg. Ez a rendelkezés is többletbiztosítékot nyújt az EU-s irányelvhez képest.

\section{ÚJ BEFEKTETÉSI FORMÁK MAGYARORSZÁGON}

A pénzügyi innováció a jogalkotót jelentôs kihívások elé állítja. Az új pénzügyi termékek és jogintézmények ugyanis rövid múlttal, de jelentôs kockázatokkal is rendelkezhetnek. Ezért szükséges a jogalkotásban egyaránt mérlegelni az innováció támogatását és a befektetôvédelem szempontjait.

\section{Alternatív befektetési formák a magyar jogban}

Az EU jogalkotói már 2010-ben belátták, hogy a sokasodó befektetési alapok szabályozása lehetetlen feladat, és csak a befektetésialap-kezelókre vonatkozó szabályok implementálása útján lehet megregulázni a piaci szereplôket. Ennek érdekében született meg az alternatív befektetésialap-kezelókrôl, valamint a 2003/41/EK és a 2009/65/EK irányelv, továbbá az 1060/2009/EK és az 1095/2010/EU rendelet módosításáról szóló 2011/61/EU irányelv (Directive on Alternative Investment Fund Managers, AIFM), mely azonban szintén biztosít lehetôséget a szabályok alól történô mentesülésre. Azok az alternatív befektetési alapok ${ }^{8}$ mentesülhetnek a szigorúbb szabályok alól, melyek 100 millió euró alatti kezelt vagyonnal rendelkeznek. Szintén mentesülnek az olyan 
alapok, melyek bár 500 millió euró kezelt vagyonnal rendelkeznek, de tókeáttételt nem alkalmaznak, és olyan befektetési jegyet bocsátanak ki, melyek nem biztosítanak öt évnél rövidebb idôszakra visszaváltási lehetôséget az általuk kibocsátott befektetési jegyek tulajdonosainak. A 2011-es AIFM-irányelv szerint két lehetséges múködési modell áll rendelkezésre. Az egyik, hogy az alapkezeló az átruházható értékpapírokkal foglalkozó kollektív befektetési vállalkozásokra (ÁÉKBV) vonatkozó törvényi, rendeleti és közigazgatási rendelkezések összehangolásáról szóló 2009/65/EK irányelv (Undertakings for the Collective Investment in Transferable Securities, UCITS) szerinti hagyományos befektetési alapként folytatja tevékenységét. A másik lehetôség, hogy az AIFM-irányelv által meghatározott szabályok szerint múködik.

2009 márciusában az AIFM-irányelv garanciális célokat ${ }^{9}$ jelölt meg az alternatív befektetési alapokat kezelô iparág tekintetében. Az elsố és legfontosabb a makroprudenciális kockázat kezelése. A makroprudenciális kockázat azt a rendszerszintú kockázatot jelöli az alternatív befektetési alap iparág esetében, melynek során a makroszintú kockázatok kialakulását előrejelzô adatgyújtés összehangoltan történik. Emellett az adatok feldolgozása a prudenciális hatóságok ${ }^{10}$ határokon átívelố együttmúködése keretében valósul meg a jogalkotó szándéka szerint. Másik részről lényeges a mikroprudenciális kockázatok kezelése, ami azokat a kockázatokat jelenti, amelyek az egyes szolgáltatók és szolgáltatások szintjén merülhetnek fel. Ezek kezelése azért volt szükséges az Európai Unióban, mert az alternatív befektetési alapok kockázatkezelési gyakorlatával és eljárási rendjével szemben nem voltak megfelelő felügyeleti elvárások. A kockázatkezelés gyakorlatának hiányosságai azonban veszélyt jelentenek a befektetôk, a szerzódéses partnerek és a piac egészének tekintetében is. A konzisztensebb szabályozás csökkentheti a befektetôk és szerződéses partnerek kockázatát, a határokon átnyúló szabályozás pedig a felügyeleti szervek közötti különbségek kihasználásának (szabályozói arbitrázs ${ }^{11}$ ) lehetôségét csökkenti (Kecskés-Bujtár, 2015).

A 2008-2009-es pénzügyi válság a befektetôk védelme érdekében is a beavatkozás szükségességét támasztotta alá. Így van ez, annak ellenére is, hogy az alternatív befektetési alapok ügyfelei jellemzôen professzionális befektetôk, de még számukra is szükséges a megbízható és teljes körú információszolgáltatás. A nemzeti szabályozások közzétételi és társaságirányítási tekintetben eltéró megközelítést alkalmaztak az EU-szabályozást megelőzôen, ezért nem is tudtak konzisztens jogi alapokat biztosítani az alternatív befektetési alapok kiszámítható múködéséhez. A piaci szabályozás egységesítése az alternatív befektetési alapok kezelésében nemcsak a pénzügyi stabilitást, de a piacok hatékonyságát és integritását is növelni tudja, függetlenül a piac múködési helyétől.

\section{A hedge fundok szabályozása}

A magyar szabályozás ezeket az irányelvi rendelkezéseket implementálta tagállami szinten, a 2014. évi XVI. törvény (a kollektív befektetési formákról és kezelôikról) szabályozási körében és a 78/2014. (III. 14.) Korm. rendelet (a kollektív befektetési formák befektetési és hitelfelvételi szabályairól) keretében. A magyar szabályozás át- 
Kecskés András: A magyar tôkepiaci szabályozás, különös tekintettel az új befektetési formák...

veszi a irányelv keretfeltételeit, sốt olyan alapvetố fogalmakat is átültet, mint a prime dealer $^{12}$, valamint az alapokba fektetố alternatív alapok helyett a gyújtôalap kifejezést használja, és a befektetés tárgyát képezô alternatív alap a célalap elnevezéssel kerül meghatározásra (Kecskés-Bujtár, 2015).

Hasonlóan az AIFM-irányelvhez, a 2014. évi XVI. törvény is kivételt tesz a 100 millió euró alatti kezelt vagyonnal rendelkezó vagy 500 millió euró kezelt vagyonnal rendelkezô, de tốkeáttételt nem alkalmazó és olyan befektetési jegyet kibocsátó alternatív befektetési alapoknál, melyek nem biztosítanak öt évnél rövidebb idôszakra visszaváltási lehetôséget az általuk kibocsátott befektetési jegyek tulajdonosainak. Azonban a magyar szabályozás, ellentétben az EU keretszabályozással, a törvény hatálya alá helyezi ezeket az alapokat is, és csak négy uniós területen engedélyez kivételt a szabályozás alól az ilyen paraméterekkel rendelkezô alapok számára: a javadalmazási, kockázatkezelési, a likviditáskezelési és visszaváltási politikára és ez utóbbi két rendszer összhangjának kérdésére vonatkozóan. A magyar szabályozás is átveszi a halasztott javadalmazási rendszer EU által meghatározott normáit. Minimum 40\%-a a teljesítményalapú javadalmazásnak csak 3-5 év késleltetéssel fizethetô ki.

Annak ellenére, hogy az EU jogi szabályozása nem egy amerikai típusú hedge fund szabályrendszert alkalmaz, a magyar szabályozás mintha ennél az európai megközelítésnél még szélesebbre tárná a lehetôségeket a hedge fundok múködését illetôen. A 78/2014. (III. 14.) Korm. rendelet 23. § (2) bekezdése lehetôvé teszi a törvény szabta szigorú korlátoktól való jelentôs eltérést. Ebben az esetben a nyilvános befektetési alap nevében a „származtatott befektetési alap” elnevezésnek szerepelnie kell, és az alábbi két feltételbôl legalább egynek teljesülnie kell: az egy befektetố által befektethetô minimális kezdô befektetés 10 millió forint, illetve befektetési jegyei csak szakmai befektetôk körében forgalmazhatók. A fenti feltételek teljesülése esetén az alap kezelési szabályzatában egyedileg meghatározható a származtatott ügyletekben lévố pozíciók összesített kockázati kitettségének mértéke. Ezzel egy olyan alternatív alap jöhet létre, amely a hedge fundok két alapvetô tulajdonságát valósítja meg: a befektetôk köre kiemelt vagyonnal rendelkezik, vagy szakmai befektetô, és magas tókeáttétel valósul meg. Az alapkezelô és a befektetôk azonos alapban történô tôkebefektetése és közös kezelése csak elkülönült jogalany bevonásával valósulhat meg (Kecskés-Bujtár, 2015).

A szabályozott ingatlanbefektetési társaságok

Az ingatlanalapok körében érdekes ingatlanalap jellegú befektetési forma az ingatlanokba fektetố fix portfóliójú alap (Real Estate Investment Trust). E formát Magyarországon szabályozott ingatlanbefektetési társaság néven ismerjük. Mai formáját hosszú fejlôdési folyamat eredményeként érte el (Sharpe et al., 1994). Az Egyesült Államokban a jogi szabályozás már 1960-tól (Real Estate Investment Trust Act of 1960) lehetôséget teremtett arra, hogy a nagy intézményi befektetôkhöz hasonlóan a lakossági befektetốk is részesedjenek az ingatlanpiac növekedéséból. Népszerúvé mégis az 1980-as évek második felétôl vált, az 1980-as évek jelzálogpiaci problémái és két kedvezó adó- 
módosítás után. Az 1970-es és az 1980-as években ugyanis a nyugdij- és életbiztosítók folyamatosan növelték ingatlanpiaci jelenlétüket. Ezek után nem meglepó, hogy a zárt végú közös ingatlanalapok nyertek teret. Esetükben ugyanis meghatározott futamidôre jött létre a közös ingatlanalap. A befektetôk úgy csatlakozhattak, hogy jegyzési árfolyamon vásárolták meg a befektetési jegyeket. Ez ugyan prémium árfolyamon történt a kezdeti teljes ingatlan- és likvid eszközportfólió értékéhez képest, de megfelelt az értékpapíralapokra is jellemzô (néhány százalék) feltöltési díjnak. Ilyen alap futamideje alatt nincs lehetôség új befektetôket bevonni, és a futamidô végéig a befektetések sem értékesíthetôk. Az így kialakult likviditási problémára több válasz is elképzelhetô a befektetôk részéről. Az egyik a befektetési jegyek hosszú távú befektetési eszközzé történô átminôsítése. A másik, hogy a másodlagos piacon hasonló befektetô vagy ingatlankezelố társaság számára értékesítik a részesedést. Az elóbbi eset azonban bizonytalan idôre kötheti le a befektetési tôkét, míg az utóbbi esetre nézve ilyen másodlagos piac még nem alakult ki (Kecskés, 2016a).

A likviditási és vagyonértékelési problémákra a tényleges megoldást a szabályozott ingatlanbefektetési társaságok jelentették. Az Egyesült Államokban az 1976-os adóreform lehetôvé tette a szabályozott ingatlanbefektetési társaságok létrehozását részvénytársasági formában is (U.S. Government, 1976:77). A társaságnak a társasági adófizetési kötelezettség terhe alóli mentesüléshez az alábbi feltételeknek kellett megfelelni: bevételeinek legalább 95\%-át kifizeti a tulajdonosoknak, az eszközeinek és bevételeinek legalább 75\%-a ingatlanalapú részvény vagy közvetlen ingatlanbefektetésból származik, legalább száz részvényese van, és olyan diverzifikált ingatlanportfólióval rendelkezik, melynek legfeljebb 30\%-a kerülhet értékesítésre négy éven belül. Ez utóbbi kitétel azt célozta, hogy ez a befektetési forma ne lehessen rövid távú ingatlanspekuláció eszköze (Sharpe et al., 1994).

A fenti kitételek között már szerepel az ingatlanalapú részvény fogalma, mely a szabályozott ingatlanbefektetési társaság lényegi jellemzője. Az ilyen alap ugyanis hasonlít a zárt végú befektetési alaphoz, de nem pénzügyi eszközökbe, hanem ingatlanokba fektet, és attól eltérô jogi formában múködik. Esetében tehát a nyilvános részvénytársasági forma és az alapításához és tôkésítéséhez kapcsolódó értékpapírosítási folyamat (részvénykibocsátás) jelenti a befektetési jegyek útján történô csatlakozás alternatíváját (Lentner, 2015). Az értékpapírosítás úgy történik, hogy az ingatlanalap kezelôje jellemzôen 35-40 ingatlant vásárol, és a finanszírozáshoz szükséges forrást szabadon átruházható részvények kibocsátásával gyújti össze (Sharpe et al., 1994). Így a részvénytársaság lesz az ingatlanok tulajdonosa és a bérleti díjak jogosultja. Emellett a részvények árfolyama az ingatlanok árfolyamát is követi. Ezzel a befektetôk mindkét problémája megoldódik, hiszen a szabályozott ingatlanbefektetési társaság részvényei szabályozott piacra is bevezethetôk. Így a likviditás és az értékesítés is biztosított nyilvánosan hozzáférhetô információk alapján. A nyilvánosság csökkenti az értékelés elfogult jellegét, hiszen a piac túlértékelés és alulértékelés esetén is reagálhat. Az alapkezelônek így elemi érdekévé válik a pontos értékelés. Emellett a részvények árfolyamának hamis értékelés útján történó manipulálása felveti a piacbefolyásolás kérdését is (Kecskés, 2016a). 
Kecskés András: A magyar tôkepiaci szabályozás, különös tekintettel az új befektetési formák...

Az ingatlanalapba történó befektetés elônye az értékpapíralapba történó befektetéssel szemben, hogy az ingatlanalap az ingatlanok üzemeltetôje marad. Ezáltal professzionális döntéshozatal alapján építtethet, adhat bérbe és értékesíthet ingatlanokat. Értékpapíralapok esetében portfóliótársaságok múködtetésében általában nem vesznek részt az alapok kezelói, legfeljebb a kifejezetten aktivista hedge fundok esetében. Az ingatlanalapú befektetések között a szabályozott ingatlanbefektetési társaság jelentôségének növekedését támasztja alá, hogy 2014-re már 1,7 billió USD értéket ért el a 456 darab ilyen típusú befektetési forma összpiaci értéke az Egyesült Államokban (Cohen \& Steers, 2014).

A 2011:CII. törvény a szabályozott ingatlanbefektetési társaságokról 2011. július 27-én lépett hatályba. Az idôzítés szinte tökéletesnek mondható abból a szempontból, hogy a 2008-2009-es subprime válságot követôen az ingatlanpiaci pánik éppen lecsengóben volt, de a piacon még nem indult be a növekedés. Így lett volna idő felkészülni és feltérképezni az új lehetôségeket. Ennek megfelelően, a piaci szereplők várakozásai szerint legalább 3-5 társaságnak kellett volna piacra lépni a törvény hatálybalépését követô 2-3 évben.

Magyarországon mégis kudarcba fulladt. Ennek okai a magas tôkekövetelmény, a tulajdonosi kör korlátozása. E problémák döntő többségét a 2016. évi adótörvényekkel együtt elfogadott törvénymódosítás (a 2016:LXVI. törvény egyes adótörvények, illetve a Nemzeti Adó- és Vámhivatalról szóló korábbi törvény módosítása) egy kivételével orvosolta. E kivétel a minimális tôkekövetelmény kérdése. A 10 milliárd forint tôkekövetelmény egyedülálló a magyar jogrendszerben, mert a kereskedelmi bankok alapításához elôírt minimális tôkekövetelmény is jóval alacsonyabb ${ }^{13}$ ennél az összegnél. A pénzintézetekhez hasonló mértékú tôkekövetelmény, a tényleges tulajdonosok körének megfelelố azonosítása és az anonim tulajdonosok kizárása megfelelô garanciát jelent a laikus és kisbefektetốk számára is. Azonban a szabályozott ingatlanbefektetési társaság versenytársai nem a pénzintézetek, hanem az ingatlanbefektetési alapok. Ezt illusztrálja, hogy 2016 februárjában a Duna House Holding Nyrt. is inkább ingatlanalapot hozott létre, amely mindössze 1 milliárd forint tókével indult el. Ennek alternatívája, a szabályozott ingatlanbefektetési társaság tízszer ekkora tôkeszükséglettel indulhatott volna el (Kecskés, 2016a).

A tôkeerôs pénzintézetek és biztosítók 2011:CII. törvény szerinti 10\%-os tulajdonosi korlátozása szintén csökkenti a bizalmat és a kapitalizációt a pénzügyi befektetôk irányából. Magyarországon esetükre nézve a korábbi túlzottan szigorú szabályozást a 2016. évi törvénymódosítás (2016:LXVI. törvény) enyhítette. A 10\%-os küszöbértéket megtartotta ugyan, de csak a szavazati jog korlátozása terén. Ugyanakkor a tulajdonszerzés korlátozását eltörölte a pénzintézetekre és a biztosítókra nézve.

Adójogi szempontból az ingatlanátruházást terhelô 2\%-os illetékteher jelentôsen csökkenti a társaság vonzerejét, bár összehasonlítva az általános (4\%-os) illetékteherrel, már foglal magában termékspecifikus kedvezményt. A 2\%-os illetékterhet a 2016. évi törvénymódosítás (2016:LXVI. törvény) nem érintette, ezért a jövőre nézve érdemes lenne megfontolni annak eltörlését, akár véglegesen, akár átmeneti kedvezmény formájában, például ötéves átmeneti idôszakra annak érdekében, hogy ez a befektetési forma népszerúbbé válhasson (Kecskés, 2016a). 


\section{ÖSSZEGZÉS}

Megállapítható, hogy a magyar tókepiaci jog igyekszik lekövetni a nemzetközi gazdasági életben történt változásokat. A tőkepiaci törvényben található szabályok, valamint az alternatív befektetés alapokra vonatkozó rendelkezések megfelelnek a jelenlegi európai uniós szabályozási rendszernek, ami azt mutatja, hogy a hazai tókepiaci jogharmonizáció sikeresnek tekinthetô. Azonban a magyar jogalkotó figyelme nemcsak az Európai Unióra terjed ki, hiszen szabályozott ingatlanbefektetési társaságok meghonosítása az USA szabályozási mintájára történt.

\section{JEGYZETEK}

1 Összehangoltan eljáró személyek: olyan természetes személyek, jogi személyek vagy egyéb szervezetek, akik vagy amelyek a céltársaságban történô befolyásszerzésre, a céltársaság irányításának megszerzésére vagy vételi ajánlat meghiúsítására irányuló megállapodás alapján múködnek együtt.

2 Céltársaság: magyarországi székhellyel rendelkezô vagy magyarországi szabályozott piacra bevezetett, nyilvánosan múködô társaság, amelynek részvényei a nyilvános vételi ajánlati eljárás tárgyát képezik.

3 Amennyiben a hasonló esetekben a szóban forgó határidôn belül kevesebb mint harminchat ügyletre kerül sor, akkor a forgalommal súlyozott átlagárat nem kell figyelembe venni.

4 Ha a céltársaság részvényeit több szabályozott piacra is bevezették, akkor az egyes szabályozott piacokon külön-külön számított átlagárak közül a legmagasabbat kell figyelembe venni azzal, hogy a forintértékre történố átszámítás során az ügyletkötés napján érvényes, a Magyar Nemzeti Bank által közzétett hivatalos devizaárfolyamot kell alkalmazni.

5 A 2001. évi CXX törvény 76/A.§ (1) és (2) alapján a céltársaság alapszabálya elôírhatja, hogy vételi ajánlat elfogadására nyitva álló idôszakban nem alkalmazható az ajánlattevốre a) a céltársaság alapszabályában foglalt, a részvények átruházására vonatkozó korlátozás; és b) a céltársaság és a részvényese közötti, illetve a céltársaság részvényesei között az alapszabály ilyen tartalmú módosítását követôen kötött megállapodásban foglalt, a részvények átruházására vonatkozó korlátozás. (2) A céltársaság alapszabálya elôírhatja, hogy a céltársaság részvényeseinek azon közgyúlésén, amely a 73/A. §-ban foglalt rendelkezésekkel összhangban védekezési intézkedésekrôl határoz, a) nem alkalmazható az alapszabályában foglalt, szavazati jogra vonatkozó korlátozás, ha a korlátozás nem a részvényesnek juttatott vagyoni előny ellentételezése; b) nem alkalmazható a céltársaság és a részvényese közötti, illetve a céltársaság részvényesei között az alapszabály ilyen tartalmú módosítását követôen kötött megállapodásban foglalt, szavazati jogra vonatkozó korlátozás, amennyiben a korlátozás nem a részvényesnek juttatott vagyoni elóny ellentételezése; és c) a többszörös szavazati jogot megtestesítố részvények - ha a többszörös szavazati jog nem valamely egyéb jog elvonásának ellentételezése - egy szavazatot érnek.

6 A 2001. évi CXX. törvény 76/A.§ (1) és (2) alapján a céltársaság alapszabálya elôírhatja, hogy ha az ajánlattevố a vételi ajánlattételi eljárás során a szavazati jogot megtestesítô részvények legalább hetvenöt százalékát megszerezte, a céltársaság részvényeseinek közgyúlését összehívhatja, kezdeményezheti az alapszabály módosítását, valamint az igazgatósági, igazgatótanácsi és felügyelôbizottsági tag visszahívását, illetve kinevezését. (2) Az (1) bekezdésben foglaltak szerinti közgyúlésen a) a 76/A. § (1) és (2) bekezdése szerinti korlátozások, valamint az igazgatósági, igazgatótanácsi és felügyelôbizottsági tag kinevezésére és visszahívására vonatkozó különleges jogok nem gyakorolhatók; és b) a többszörös szavazati jogot biztosító részvények - ha a többszörös szavazati jog nem valamely egyéb jog elvonásának ellentételezése - egy szavazatot érnek.

7 Saját tôkeként a legutolsó, könyvvizsgáló által hitelesített éves beszámolóban feltüntetett értéket kell figyelembe venni azzal, hogy ha a társaság a számviteli jogszabályok értelmében összevont (konszolidált) beszámoló készítésére kötelezett, akkor saját tőkén a konszolidált saját tôke értendô. 
Kecskés András: A magyar tôkepiaci szabályozás, különös tekintettel az új befektetési formák...

8 Alternatív befektetési alapok: a hagyományos befektetési alapoktól eltérô és az azokra vonatkozó szabályozás körén kívül esố tôkegyújtố szervezetek, melyek a többi befektetési alaptól eltérôen nem helyeznek hangsúlyt a diverzifikált portfóliók kialakítására, nagy volumenben alkalmaznak tôkeáttétet és származékos ügyleteket.

9 http://ec.europa.eu/finance/investment/docs/20121219-directive/ia_en.pdf.

10 Prudenciális hatóságok: a tőkepiaci felügyeletet ellátó hatóságok köre.

11 A szabályozási arbitrázs során az egyes szolgáltatók a kedvezôbb vagy enyhébb szabályozási környezetet biztosító országot választják múködési székhelyükként, mely döntésnek lehet ugyan költségvonzata is, de az elsôdleges szempont az egyszerúbb és kevesebb teherrel járó múködés.

12 Prime dealer: az a pénzügyi szolgáltató, mely a befektetési alap számára nemcsak számlavezetési, de egyben finanszírozási szolgáltatásokat is nyújt. A szolgáltatások jellege miatt ezt a megoldást az Egyesült Államokban jellemzốen befektetési bankok látják el, míg Európában inkább a kereskedelmi bankok végzik.

13 A hitelintézetekrôl és a pénzügyi vállalkozásokról szóló 2013:CCXXXVII. törvény alapján mindösszesen kétmilliárd forint mind a (kereskedelmi) bank, mind a pénzügyi holding esetében.

\section{FELHASZNÁLT IRODALOM}

Bujtár Zsolt - Kecskés András (2015): Felfedezni a fedezetlent? Körkép a hedge fundokban rejlô lehetôségekrôl és kockázatokról. Debreceni Jogi Mühely, 12. évf., 3-4. sz., https://doi.org/10.24169/djm/2015/3$4 / 1$.

Cohen \& Steers (2014): Introduction to Real Estate Securities. https://www.cohenandsteers.com/assets/content/resources/insight/Introduction_Real_Estate_Securities.pdf.

Gadó Gábor (2000): A társasági és cégjogi szabályozás továbbfejlesztésének irányai. Gazdaság és Jog, 8. évf., 7-8. sz., 3-19.

Kecskés András (2010): A felelós társaságirányítás fejlódési tendenciái. Szabályozási koncepciók Európában és az Egyesült Államokban. PhD-értekezés, Pécsi Tudományegyetem, Pécs, http://ajk.pte.hu/files/file/doktori-iskola/kecskes-andras/kecskes-andras-vedes-tezisek.pdf.

Kecskés András - Halász Vendel (2011): Társaságok a tôzsdén. HVG-ORAC, Budapest.

Kecskés, András - Halász, Vendel (2013): Stock Corporations. A Guide to Initial Public Offerings, Corporate Governance and Hostile Takeovers. HVG-ORAC - LexisNexis, Budapest-Wien.

Kecskés András (2016a): A szabályozott ingatlanbefektetési társaságok Magyarországon. Controller Info, 4. évf., 4. sz., 20-24.

Kecskés, András (2016b): Hungarian Capital Markets Regulation. In: Sándor, István (ed.): Business Law in Hungary. Patrocinium, Budapest, 463-481.

Lentner Csaba (2015): A túlhitelezés globalizálódása a világban és Magyarországon. In: Lentner Csaba (szerk.): A devizahitelezés nagy kézikönyve. Nemzeti Közszolgálati és Tankönyvkiadó, 23-62.

Lentner, Csaba (2017): Scientific Taxonomy of Hungarian Public Finances After 2010. Polgári Szemle / Civic Review, Vol. 13, Special Issue, 21-38, https://doi.org/10.24307/psz.2017.0303.

Lentner Csaba - Zéman Zoltán (2017): A pénzügyi válság bankszabályozási controll elveinek meghatározóbb történeti elemei. Európai Jog, 17. évf., 1. sz., 8-13.

Sándor Tamás (2002): Vállalatfelvásárlás a magyar jogban. In: Sárközy Tamás - Vékás Lajos (szerk.): Eörsi Gyula emlékkönyv. HVG-ORAC, Budapest.

Sharpe, William F. - Alexander, Gordon - Bailey, Jeffrey V. (1994): Investments. Prentice Hall Professional.

Tomori, Erika (2016): Értékpapirjog és a tôkepiac szabályozása. Közép-európai Brókerképzố Alapítvány, Budapest.

U.S. Government (1976): Summary of the Tax Reform Act of 1976. U.S. Government, Washington, www.jct. gov/s-31-76.pdf.

Visegrády Antal (1995): A jog hatékonyságának problémái. Magyar Jog, 42. évf., 1. sz., 6-16. 